\title{
Natural Fibers Derived from Coi (Streblus asper Lour.) and their Behavior in Pulping and as Paper
}

\begin{abstract}
Wisanee Boonpitaksakul, Korawit Chitbanyong, Buapan Puangsin, Sawitree Pisutpiched, and Somwang Khantayanuwong *

The Siamese people utilized the bark of the Coi tree (Streblus asper Lour.) to manufacture paper approximately 330 years ago. However, there are no studies yet related to the chemical properties of Coi bark as well as the morphological properties of Coi bark fiber and Coi pulp fiber. This research paper discussed such properties of Coi bark. The results indicated that Coi bark possessed a chemical composition that could potentially be used for pulp production, although it contained a high value of ash content, due to many calcium particles in the bark. Even though Coi pulp fibers were very long and stiff, with small lumens and thick cell walls, they could be felted naturally on a washing screen to make a strong wet sheet. This was due to a high felting power of fibers derived from a high value of fiber length and slenderness ratio. Therefore, the handsheets produced from Coi pulp fiber were obtained without chemical and beating treatments. These observations mean that both the archaeological and industrial applications of Coi bark, i.e., an ancient Samud Coi preservation and a new potential source of pulp fiber, are possible.
\end{abstract}

Keywords: Coi; Streblus asper Lour.; Chemical properties; Morphological properties; Pulp; Paper

Contact information: Department of Forest Products, Faculty of Forestry, Kasetsart University, Bangkok 10900, Thailand; *Corresponding author: fforsok@ku.ac.th

\section{INTRODUCTION}

In Thailand, the first record of Siamese (or Thai people) handmade paper was by Monsieur de la Loubère, envoy extraordinaire from the French king to the king of Siam, during the years 1687 and 1688. In his record, he stated that the handmade paper was made from old cotton rags and the bark of Ton Coi tree. Such the paper had low quality, body, and whiteness. Therefore, Siamese often make the paper black with lampblack-like coating to improve its surface smoothness and body. The paper is known as "Coi paper" and the term "Samud Coi" refers to the books produced by folding Coi paper in and out like a fan. The length of Samud Coi is very long, and is not bound (La Loubère 1693; Veeraprachak 1987). An ancient Samud Coi is shown in Fig. 1.

Figure 2 shows the plant morphology of Ton Coi or Coi (Streblus asper Lour.) in the family Moraceae. It is a small tree distributed in India, Sri Lanka, Malaysia, the Philippines and Thailand (Gadidasu et al. 2011). Siam rough brush tree, Kak Mai Foi, and Som Po are the other local common names of Coi in different geographical parts of Thailand. As mentioned above, the Siamese or Thai people utilized the paper produced from Coi bark to make their own books or "Samud Coi" at least 330 years ago. However, it seems that Coi paper and Samud Coi have disappeared from daily use in Thailand today. Therefore, a majority of Coi paper and Samud Coi can be seen only in museums as archives and archaeological material. 


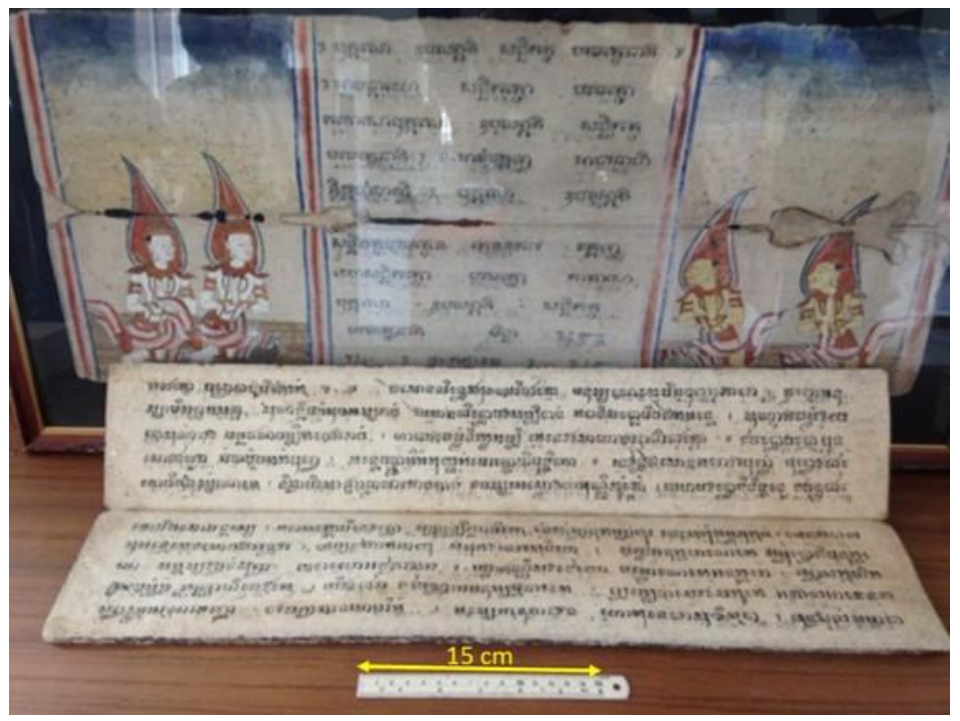

Fig. 1. An ancient Samud Coi

Only a few studies have been conducted to date that report on the cultural and archaeological aspects of Coi paper and Samud Coi (Veeraprachak 1987; Srivorapot and Saengtub 1999). Because there is no scientific information related to the use of Coi bark as a raw material for pulping and papermaking, it is important to focus on scientifically investigating the chemical properties and fiber morphology of the Coi bark. A chemical pulping condition was assigned to determine the possibility of using Coi bark in pulp and paper production. In the future, these essential data are expected to be useful in both archaeological and industrial applications, i.e., an ancient Samud Coi preservation and a potential new source of pulp fiber.

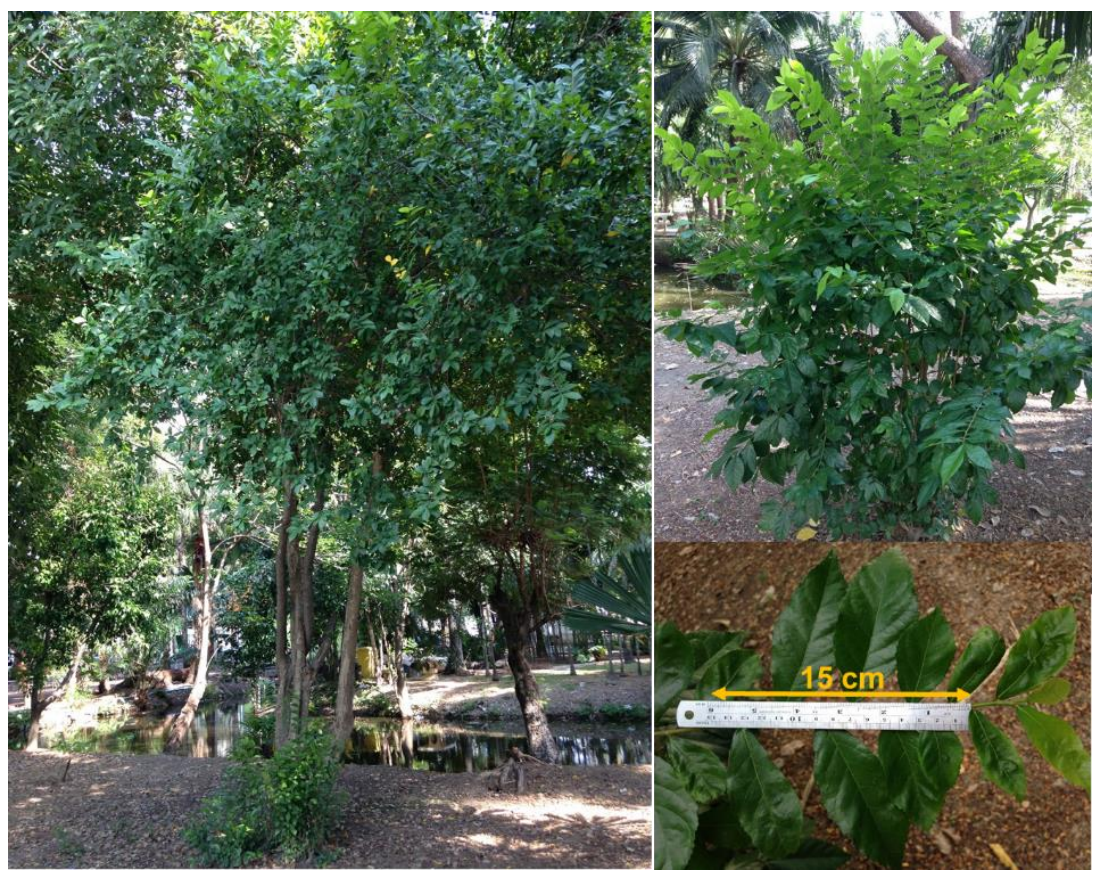

Fig. 2. Coi trees (Streblus asper Lour.) in the family Moraceae 


\section{EXPERIMENTAL}

\section{Materials}

For this research, Coi wood and peeled Coi bark strips were provided by Ko Koet Royal Folk Arts and Crafts Center located in the Ko Koet sub-district, Bang Pa-in district Phra Nakhon Si Ayutthaya province, Thailand, as shown in Fig. 3. Commercial hardwood, softwood, and cotton pulp fibers provided by Thai Paper Co., Ltd. (Bangkok, Thailand) and the Bank of Thailand (Bangkok, Thailand), were used for comparing the fiber morphology with that of Coi bark fiber and Coi pulp fiber.

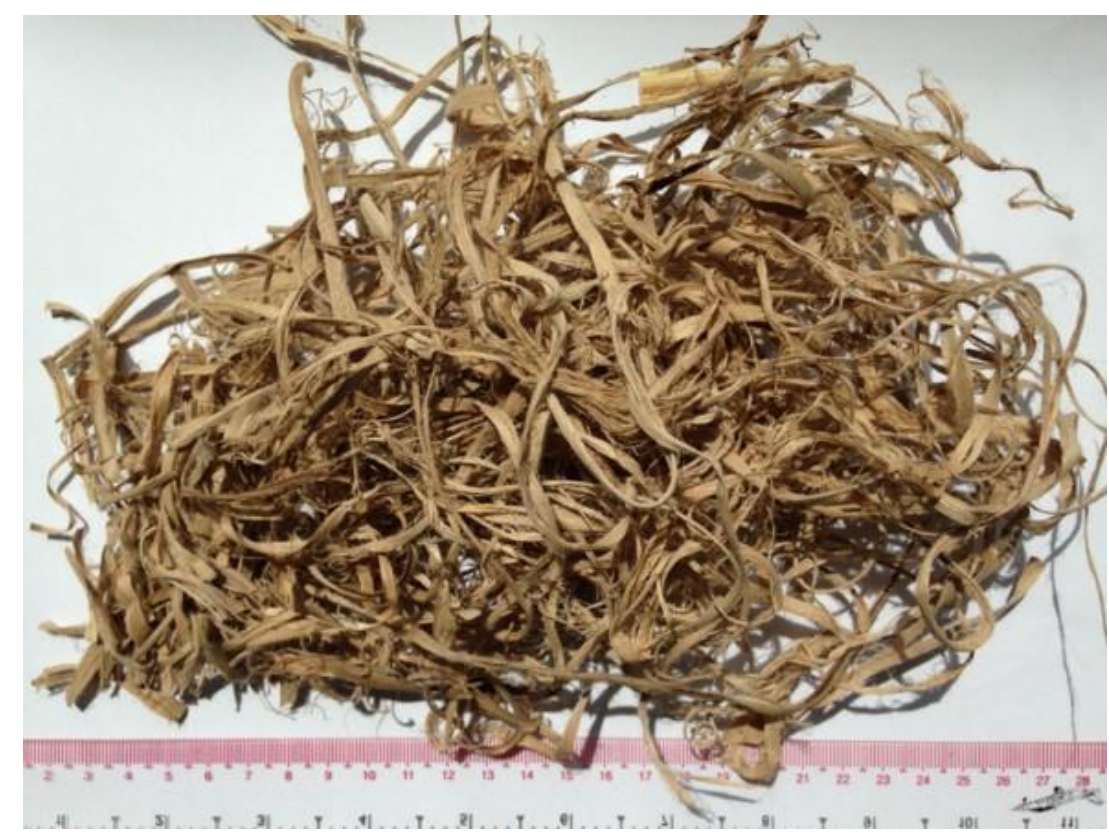

Fig. 3. Peeled Coi bark strips

\section{Methods}

Chemical composition analysis

The peeled Coi bark strips were cut into pieces 2 to $4 \mathrm{~cm}$ in length and ground into powder form using a laboratory mill (Thomas-WILEY Model 4; Arthur H. Thomas Company, Philadelphia, PA, USA). The Coi bark powder thus obtained was sieved through a 40-mesh screen and retained on a 60-mesh screen. The retained Coi bark powder was then subjected to a chemical composition analysis.

Alpha-cellulose was determined according to TAPPI T203 cm-09 (2009), alcoholbenzene extractives according to TAPPI T204 cm-07 (2007), ash content according to TAPPI T211 om-07 (2007), lignin according to TAPPI T222 om-11 (2011), pentosan content according to TAPPI T223 cm-10 (2010), water solubility according to TAPPI T207 cm-08 (2008), and solubility in 1\% NaOH according to TAPPI T212 om-07 (2007). The holocellulose content of extractive-free wood was determined according to Wise's method (Wise et al. 1946). A piece of Coi bark was investigated using a scanning electron microscope using energy dispersive X-ray spectroscopy (SEM/EDX) (SU8020; Hitachi, Tokyo, Japan). 


\section{Pulping and handsheet making}

For a comparison with the ancient method that utilized lime $(\mathrm{CaO})$ as the pulping chemical (Veeraprachak 1987), soda pulping was used to determine the potential of using Coi bark in pulp production. Soda pulping is also commonly used with non-wood fibrous raw materials (Anapanurak and Puangsin 2001).

In this research, soda pulping was completed using a laboratory rotating batch reactor (7-L Digester, SEW-Eurodrive, Bruchsal, Germany). Three samples of the peeled Coi bark strips, which were cut into 2 to $4 \mathrm{~cm}$ in length, weighing $200 \mathrm{~g}$ (oven-dry weight) were separately subjected to pulping using $6 \% \mathrm{NaOH}$ at a 5:1 liquor to bark ratio and at a maximum temperature of $165^{\circ} \mathrm{C}$. The heating time to reach the maximum temperature was $1 \mathrm{~h}$. The maximum temperature was also maintained for $1 \mathrm{~h}$ for pulping. The amount of Coi pulp fiber yield and that of the rejects was calculated after washing and screening the pulp fiber. Kappa numbers of the pulp fiber were determined using a reaction volume (in $\mathrm{mL}$ ) of $0.1 \mathrm{~N}$ potassium permanganate solution consumed by one gram of moisture-free pulp according to TAPPI T236 om-06 (2006). The assigned pulping process was repeated using $8,10,12$, and $14 \% \mathrm{NaOH}$. Both the Kappa number and yield of pulp fiber were used in determining the potential of Coi bark in pulp production. According to ISO 5269-1 (2005), some handsheet samples produced with Coi pulp fiber were used to determine the potential of Coi pulp fiber in paper production. No chemical nor beating treatments were performed during the preparation of handsheets. The handsheet samples were also observed under a scanning electron microscope (SU8020; Hitachi, Tokyo, Japan).

\section{Fiber morphology}

A piece of peeled Coi bark strip, approximately $4 \mathrm{~cm}$ in length, was macerated with a solution consisting of $30 \% \mathrm{H}_{2} \mathrm{O}_{2}$ and glacial acetic acid at a $1: 1$ ratio at $75{ }^{\circ} \mathrm{C}$ for a duration of $48 \mathrm{~h}$, according to the Franklin method (Franklin 1945). After maceration, the Coi bark fibers were disintegrated and stained with $1 \%$ safranin before analysis of the fiber morphology with a light microscope (BX50; Olympus, Tokyo, Japan). A total of 100 stained fibers were measured for their fiber length, fiber width, lumen width, and cell wall thickness. The slenderness ratio (fiber length/fiber width), Runkel ratio ([2 $\times$ cell wall thickness]/lumen width), and flexibility (lumen width/fiber width) were then calculated. The macerated fibers were also observed under a scanning electron microscope. In this research, the fibers derived from a macerated piece of Coi wood and Coi pulp were compared with those derived from commercial hardwood, softwood, and cotton pulp.

\section{RESULTS AND DISCUSSION}

\section{Chemical Composition}

The chemical composition of Coi bark is listed in Table 1. Coi bark possessed a higher level of holocellulose, alpha-cellulose, and pentosan compared to paper mulberry (Broussonetia papyrifera) bark. However, the lignin content and pentosan in the Coi bark was lower than that of kenaf (Hibiscus cannabinus) bark. These results could indicate a high potential of Coi bark in pulp production.

The $1 \% \mathrm{NaOH}$ solubility of Coi bark was lower and higher than that of kenaf and paper mulberry, respectively. This meant that it was harder to decompose the Coi bark naturally than paper mulberry but it was easier to decompose than kenaf, respectively (Udohitinah and Oluwadare 2011). The ash content of Coi bark was higher than that of 
paper mulberry and kenaf. This was because there were many cubic calcium particles in its bark, as demonstrated in Fig. 4. These phenomena were consistent with the fact that Coi leaves and bark are naturally rough like sandpaper. Therefore, if possible, procedures for the proper harvesting of Coi bark and the recovery of pulping chemicals should be considered.

Table 1. Comparison of Chemical Composition of Coi Bark with Paper Mulberry Bark and Kenaf Bark

\begin{tabular}{|c|c|c|c|}
\hline \multirow{2}{*}{ Chemical Compositions } & \multicolumn{3}{|c|}{$\begin{array}{l}\text { Content } \\
\text { (\% Oven-dry Weight of Raw Material) }\end{array}$} \\
\hline & Coi & Paper Mulberry* & Kenaf $^{* *}$ \\
\hline Holocellulose & $79.62 \pm 0.17$ & 71.03 & 71.60 \\
\hline$\alpha$-cellulose & $65.52 \pm 0.24$ & 62.14 & - \\
\hline Pentosans & $14.78 \pm 0.22$ & 8.11 & 21.00 \\
\hline Lignin & $6.02 \pm 0.21$ & - & 17.40 \\
\hline Acid-soluble lignin & $1.66 \pm 0.11$ & - & - \\
\hline Acid-insoluble lignin & $4.36 \pm 0.18$ & 3.32 & - \\
\hline Alcohol-benzene extractive & $6.29 \pm 0.63$ & 4.11 & 4.00 \\
\hline Hot water solubility & $4.74 \pm 0.27$ & 18.69 & - \\
\hline Cold water solubility & $3.15 \pm 0.14$ & - & - \\
\hline $1 \% \mathrm{NaOH}$ solubility & $36.62 \pm 0.08$ & 42.70 & 31.40 \\
\hline Ash content & $8.45 \pm 0.06$ & 4.30 & 3.10 \\
\hline \multicolumn{4}{|c|}{$\begin{array}{l}\text { Note: The data are shown as mean } \pm 95 \% \text { confident interval; }{ }^{*} \text { Anapanurak and Puangsin } \\
(2001) ;{ }^{* *} \text { Clark (1969) }\end{array}$} \\
\hline
\end{tabular}
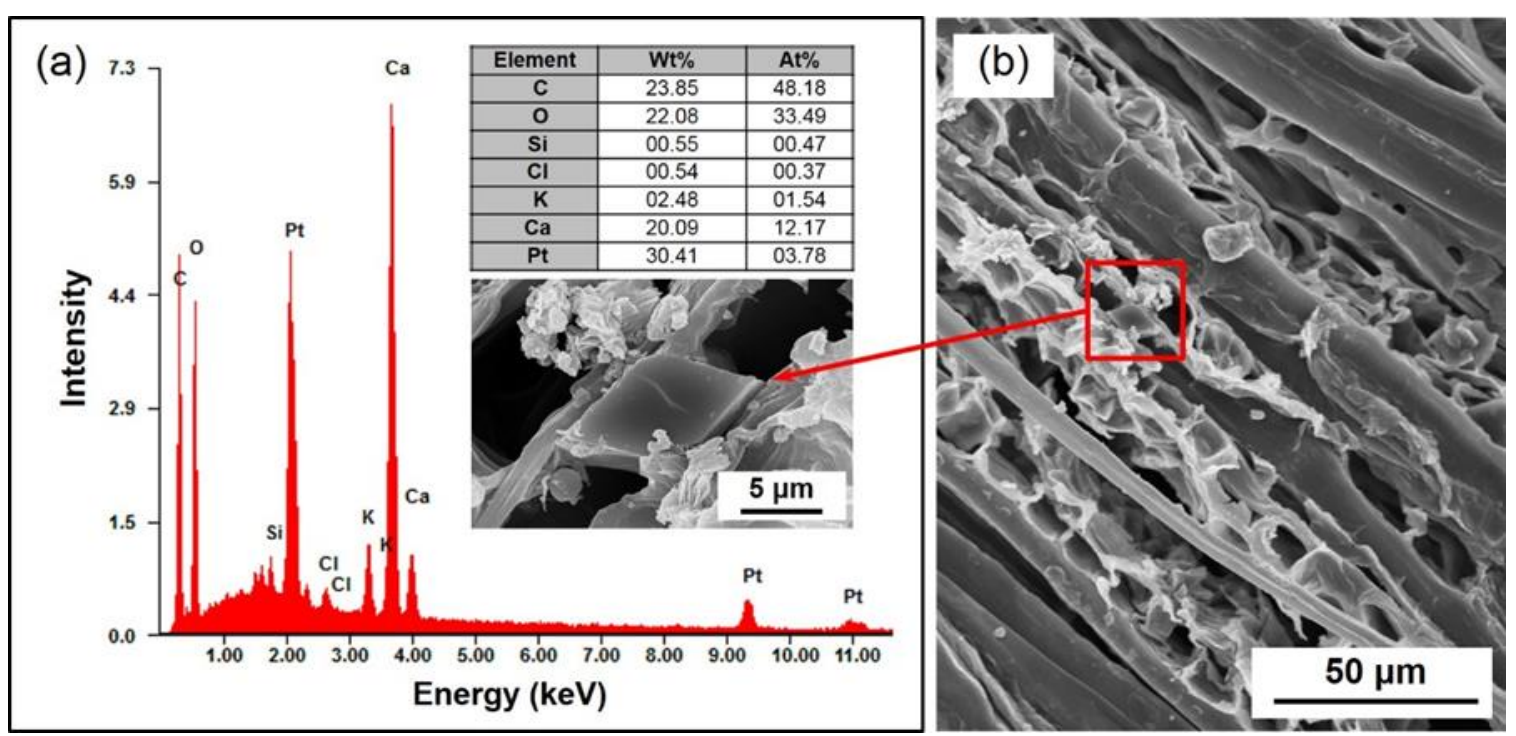

Fig. 4. An EDX of cubic calcium particles in Coi bark (a) and a scanning electron micrograph of Coi bark (b) 


\section{Pulping and Handsheet Making}

Figure 5 shows that the pulp yield and kappa number dramatically decreased from $48.35 \pm 1.70 \%$ to $43.99 \pm 1.32 \%$ and $47.94 \pm 1.02$ to $35.74 \pm 0.14$, respectively, with an increase in the concentration of $\mathrm{NaOH}$ from $6 \%$ to $10 \%$. However, there was no difference in pulp yield with an increase in the concentration of $\mathrm{NaOH}$ from $10 \%$ to $14 \%$, while the Kappa number decreased from $35.74 \pm 0.14$ to $28.56 \pm 0.33$. Additionally, from the view point of pulping and bleaching practices, the preferred pulp yield should not be less than $40 \%$ and the Kappa number not more than 30 . Therefore, in this research, the appropriate concentration of $\mathrm{NaOH}$ suggested for producing Coi pulp fiber with soda pulping was $14 \%$. Figure 6(a) shows a Coi pulp fiber mat naturally felted on a washing screen. The fiber was excellent in its wet sheet strength during forming, which was not the case with any wood or non-wood pulp fiber. This observation possibly could have facilitated the manufacturing of Coi paper by the ancient Siamese. Furthermore, the handsheets produced with Coi pulp fiber were used in a preliminarily study for the possible application of Coi pulp fiber in paper production. Figure 6(b) confirms that the handsheets could be produced with Coi pulp fiber without any chemical and beating treatment. The Coi pulp fiber possessed a Canadian Standard Freeness of $381 \pm 12 \mathrm{~mL}$ (mL CSF). A scanning electron micrograph of the handsheets is shown in Fig. 6(c). As shown, many cubic calcium particles remained on the surface of the handsheets, possibly due to their lower chemical deterioration.

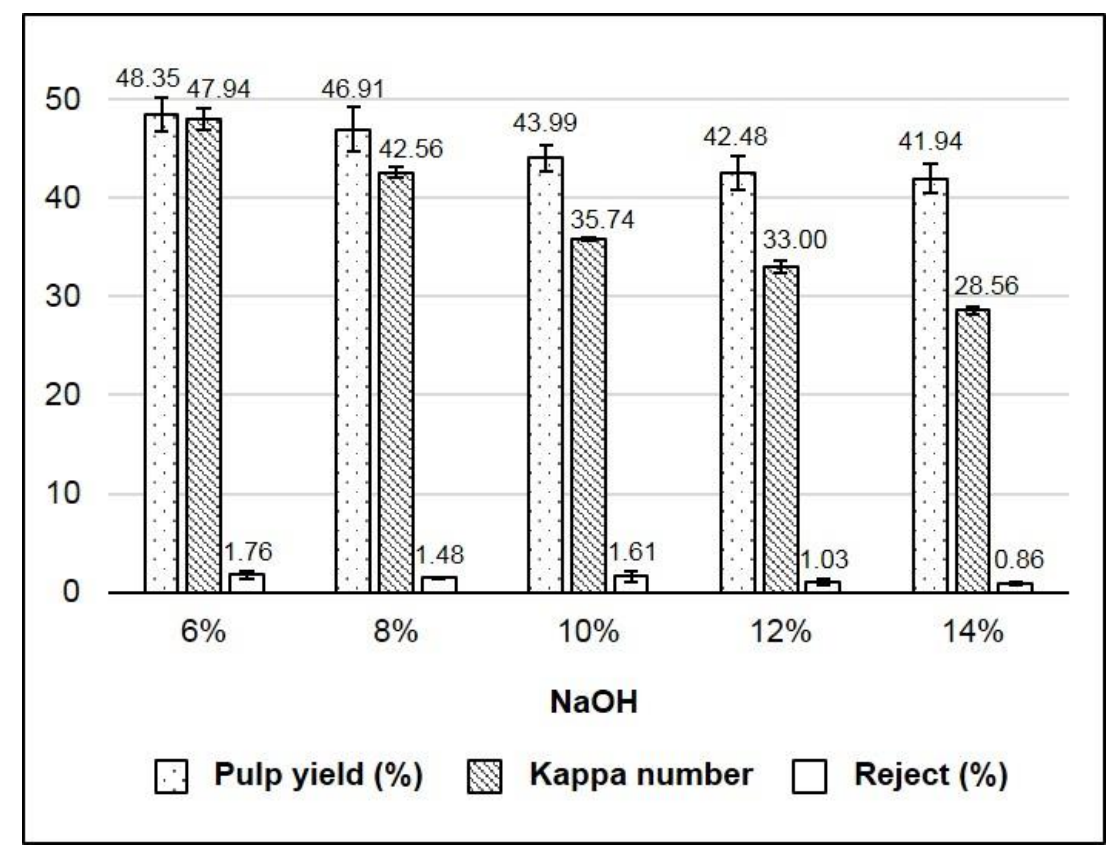

Fig. 5. Changes in Coi pulp yield and Kappa number with soda pulping; the data are shown as mean $\pm 95 \%$ confident interval

\section{Fiber Morphology}

As shown in Tables 2 and 3, even though Coi bark and Coi pulp fiber were longer than the other fibers, with a length of $12.10 \pm 0.28 \mathrm{~mm}$ and $9.96 \pm 0.31 \mathrm{~mm}$, respectively, the shorter fiber length of Coi pulp was possibly due to pulping effects. Both possessed a slenderness ratio of $530.45 \pm 18.32$ and $425.55 \pm 14.37$, which was higher than that other fibers, except for cotton lint and paper mulberry fiber. Their Runkel ratio was higher than others with a value of $2.75 \pm 0.17$ and $2.63 \pm 0.14$. 

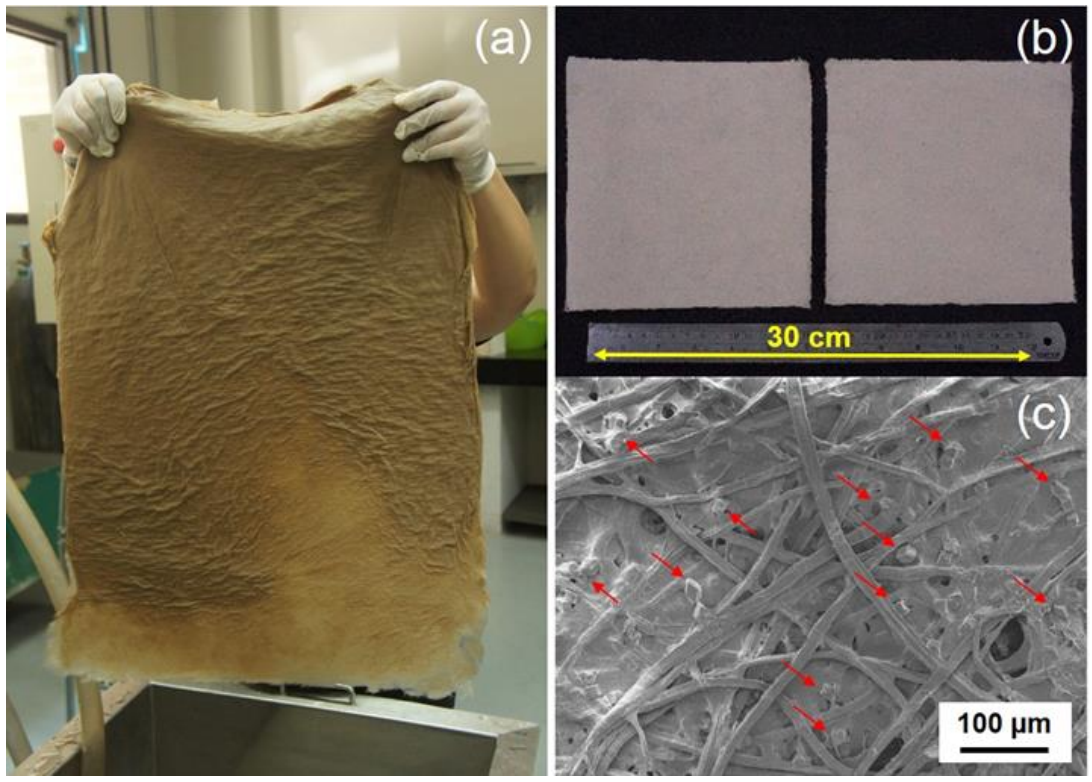

Fig. 6. (a) Coi pulp fiber mat felted on a washing screen; (b) Coi pulp fiber handsheets; (c) A scanning electron micrograph of cubic calcium particles left on the surface of Coi pulp fiber handsheet (indicated by arrows)

Meanwhile, the fiber flexibility was the lowest with a value of $0.28 \pm 0.01$. This could have been due to both the Coi bark and Coi pulp fiber being very long and stiff with small lumens and thick cell walls, as the preferred Runkel ratio and flexibility should not be above 1.00 and not below 0.50, respectively (Tofanica et al. 2011). Retulainen et al. (1998) stated that long fibers usually possess thick cell walls due to a mature lignified fiber cell wall. Even though Coi pulp fiber was stiff, as seen in Fig. 6(a), it could still be felted naturally on a washing screen to make a strong wet sheet (or mat). This was due to a high fiber length and slenderness ratio, which corresponded to a high felting power, which is essential for the strength of the derived paper sheet (Tofanica et al. 2011). Light and scanning electron micrographs of Coi bark fibers are demonstrated in Fig. 7.

Table 2. Morphological Properties of Fibers Derived from Various Sources

\begin{tabular}{|c|c|c|c|c|}
\hline \multirow{2}{*}{ Fiber Sources } & \multicolumn{4}{|c|}{ Fiber Morphological Properties } \\
\cline { 2 - 5 } & $\begin{array}{c}\text { Fiber Length } \\
(\mathbf{m m})\end{array}$ & $\begin{array}{c}\text { Fiber Width } \\
(\boldsymbol{\mu m})\end{array}$ & $\begin{array}{c}\text { Lumen Width } \\
(\boldsymbol{\mu m})\end{array}$ & $\begin{array}{c}\text { Cell Wall } \\
\text { Thickness }(\boldsymbol{\mu m})\end{array}$ \\
\hline Coi wood fiber & $1.79 \pm 0.08$ & $28.66 \pm 0.88$ & $16.98 \pm 0.73$ & $5.84 \pm 0.40$ \\
\hline Coi bark fiber & $12.10 \pm 0.28$ & $23.24 \pm 0.68$ & $6.40 \pm 0.25$ & $8.42 \pm 0.32$ \\
\hline Coi pulp fiber & $9.96 \pm 0.31$ & $23.50 \pm 0.30$ & $6.69 \pm 0.23$ & $8.40 \pm 0.18$ \\
\hline Paper mulberry fiber ${ }^{* *}$ & 8.44 & 17.5 & 5.1 & 6.2 \\
\hline Cotton lint & $7.94 \pm 0.15$ & $7.41 \pm 0.31$ & $2.85 \pm 0.13$ & $2.28 \pm 0.12$ \\
\hline Cotton linter & $1.58 \pm 0.06$ & $26.96 \pm 0.57$ & $14.61 \pm 0.55$ & $6.18 \pm 0.36$ \\
\hline Hardwood pulp fiber & $1.05 \pm 0.05$ & $29.75 \pm 1.06$ & $16.96 \pm 0.69$ & $6.39 \pm 0.54$ \\
\hline Softwood pulp fiber & $3.27 \pm 0.14$ & $37.12 \pm 1.41$ & $13.93 \pm 0.99$ & $11.59 \pm 0.72$ \\
\hline $\begin{array}{l}\text { Note: The data are shown as mean } \pm 95 \% \\
\text { method (Franklin 1945); }{ }^{* *} \text { (Anapanurak and Puangsin 2001) }\end{array}$ \\
\hline
\end{tabular}


Table 3. Calculated Morphological Properties of Fibers Derived from Various Sources

\begin{tabular}{|c|c|c|c|}
\hline \multirow{2}{*}{ Fiber Sources } & \multicolumn{3}{|c|}{ Calculated Fiber Morphological Properties } \\
\cline { 2 - 4 } & Slenderness Ratio & Runkel Ratio & Flexibility \\
\hline Coi wood fiber & $63.73 \pm 3.14$ & $0.82 \pm 0.21$ & $0.60 \pm 0.02$ \\
\hline Coi bark fiber & $530.45 \pm 18.32$ & $2.75 \pm 0.17$ & $0.28 \pm 0.01$ \\
\hline Coi pulp fiber & $425.55 \pm 14.37$ & $2.63 \pm 0.14$ & $0.28 \pm 0.01$ \\
\hline Paper mulberry fiber ${ }^{* *}$ & 483.65 & 2.46 & 0.29 \\
\hline Cotton lint & $1114.04 \pm 44.99$ & $1.65 \pm 0.09$ & $0.39 \pm 0.01$ \\
\hline Cotton linter & $59.08 \pm 2.70$ & $0.91 \pm 0.08$ & $0.55 \pm 0.02$ \\
\hline Hardwood pulp fiber & $36.08 \pm 1.81$ & $0.82 \pm 0.10$ & $0.58 \pm 0.02$ \\
\hline Softwood pulp fiber & $89.29 \pm 3.16$ & $1.99 \pm 0.24$ & $0.38 \pm 0.03$ \\
\hline $\begin{array}{l}\text { Note: The data are shown as mean } \pm 95 \% \text { confident interval; }{ }^{*} \text { Fibers derived by maceration } \\
\text { method (Franklin 1945); ** (Anapanurak and Puangsin 2001) }\end{array}$ \\
\hline
\end{tabular}
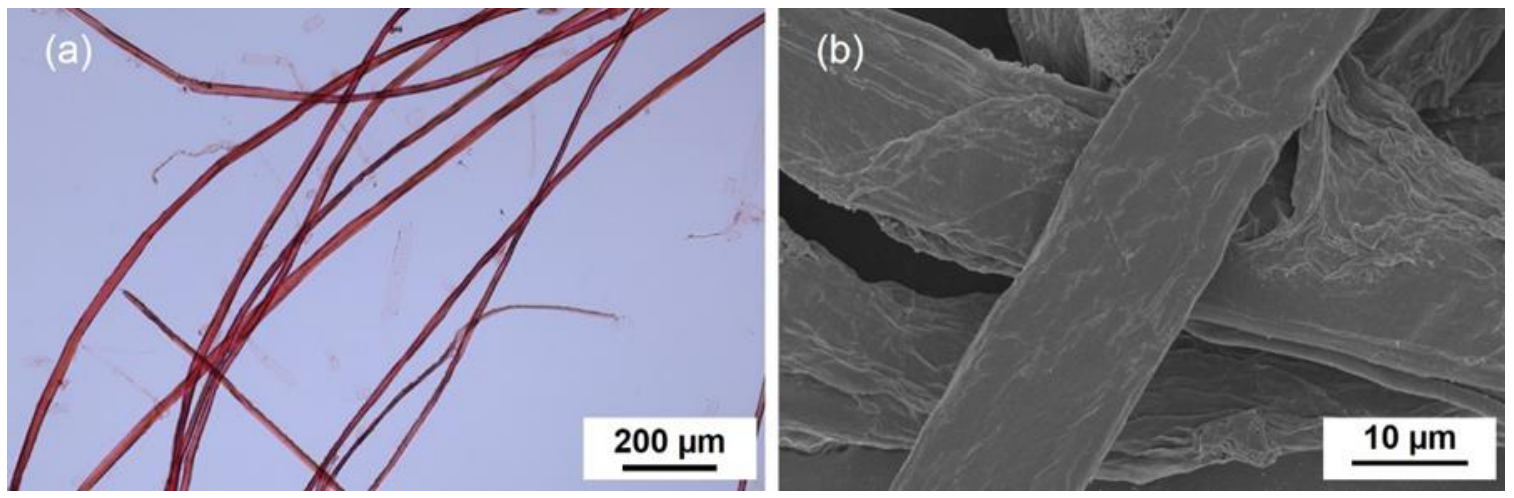

Fig. 7. Light (a) and scanning electron (b) micrographs of Coi bark fibers

\section{CONCLUSIONS}

1. The authors report, for the first time, the chemical properties of Coi bark as well as the morphological properties of Coi bark and Coi pulp fiber. The results demonstrated that Coi bark has the potential for use in the production of pulp fiber, even though it possesses a high ash content due to many cubic calcium particles in the bark.

2. Even though both Coi bark and Coi pulp fibers were very long and stiff, with small lumens and thick cell walls, the pulp fiber could be felted naturally on a washing screen to make a strong wet sheet (or mat). This was because of the high fiber length and slenderness ratio values that were essential in determining the strength of a paper sheet due to a high felting power of the fiber.

3. Handsheets derived from Coi pulp fiber were obtained without any further chemical and beating treatment. This means that handmade paper can be easily produced with Coi pulp fiber as it was produced 330 years ago in Thailand. Both the archaeological and industrial applications of Coi bark, i.e., ancient Samud Coi preservation and a new potential source of pulp fiber, are possible. 


\section{ACKNOWLEDGMENTS}

This research was supported in part by the Graduate Program Scholarship from the Graduate School, Kasetsart University. The Kasetsart University Research and Development Institute (KURDI) is also acknowledged for financial support of the work.

\section{REFERENCES CITED}

Anapanurak, W., and Puangsin, A. (2001). "Paper mulberry pulp properties by various alkaline processes," in: Proceedings of the International Symposium on Paper Mulberry and Hand-Made Paper for Rural Development, Bangkok, Thailand, pp. 309-316.

Clark, T. F. (1969). "Annual crop fibers and the bamboos," in: Pulp and Paper Manufacture: Control, Secondary Fiber, Structural Board, Coating, R. G. Macdonald and J. N. Frankin (eds.), McGraw Hill, New York, NY, USA, pp. 1-74.

Franklin, G. L. (1945). "Preparation of thin sections of synthetic resins and wood-resin composites, and a new macerating method for wood," Nature 155, 51.

Gadidasu, K., Umate, P., Aileni, M., Kota, S.R., Kokkirala, V. R., Kasula, K., and Abbagani, S. (2011). "Micropropagation of a valuable ethnomedical plant Streblus asper Lour," Journal of Phytology 3(2), 18-23.

ISO 5269-1 (2005). "Pulp-Preparation of laboratory sheets for physical testing-Part 1: Conventional sheet-former method," International Organization for Standardization, Geneva, Switzerland.

La Loubère, S. (1693). A New Historical Relation of the Kingdom of Siam, Bell \& Howell Company, Cleveland, OH, USA.

Retulainen, E., Niskanen, A., and Nilson, N. (1998). "Fibers and bonds," in: Paper Physics, K. Niskanen (ed.), Fapet Oy, Helsinki, Finland, pp. 55-87.

Srivorapot, B., and Saengtub, P. (1999). Samud Coi, Office of the Welfare Promotion Commission for Teachers and Education Personnel, Bangkok, Thailand. (in Thai)

TAPPI T203 cm-09 (2009). “Alpha-, beta-, gamma-cellulose in pulp,” TAPPI Press, Atlanta, GA, USA.

TAPPI T204 cm-07 (2007). "Solvent extractives of wood and pulp," TAPPI Press, Atlanta, GA, USA.

TAPPI T207 cm-08 (2008). "Water solubility of wood and pulp," TAPPI Press, Atlanta, GA, USA.

TAPPI T211 om-07 (2007). "Ash in wood, pulp, paper and paperboard: Combustion at $525{ }^{\circ} \mathrm{C}$," TAPPI Press, Atlanta, GA, USA.

TAPPI T212 om-07 (2007). "One percent sodium hydroxide solubility of wood and pulp,” TAPPI Press, Atlanta, GA, USA.

TAPPI T222 om-11 (2011). "Acid-insoluble lignin in wood and pulp," TAPPI Press, Atlanta, GA, USA.

TAPPI T223 om-10 (2010). "Pentosans in wood and pulp," TAPPI Press, Atlanta, GA, USA.

TAPPI T236 om-06 (2006). “Kappa number of pulp,” TAPPI Press, Atlanta, GA, USA.

Tofanica, B. M., Cappelletto, E., Gavrilescu, D., and Mueller, K. (2011). "Properties of rapeseed (Brassica napus) stalks fibers," Journal of Natural Fibers 8(4), 241-262.

DOI: $10.1080 / 15440478.2011 .626189$ 
Udohitinah, J. S., and Oluwadare, A. O. (2011). "Pulping properties of kraft pulp of Nigerian-grown kenaf (Hibiscus cannabinus L.)," BioResources 6(1), 751-761. DOI: 10.15376/biores.6.1.751-761

Veeraprachak, K. (1987). Thai Long Book Production and Palm Leaf Manuscripts Preparation, Fine Arts Department of Thailand, Bangkok, Thailand. (in Thai)

Wise, L. E., Murphy, M., and D'Addieco, A. A. (1946). "Chlorite holocellulose, its fractionation and bearing on summative wood analysis and on studies on hemicelluloses," Paper Trade Journal 122(2), 35-43.

Article submitted: May 9, 2019; Peer review completed: June 17, 2019; Revised version received and accepted: June 20, 2019; Published: 10.15376/biores.14.3.6411-6420 